\title{
Interactive Customer Relationship Management Jasa Infrastruktur Jaringan PT. Meda Cipta Hutama
}

\author{
R. H. Handayani, Q. Aini, E. Nurmiati
}

\begin{abstract}
PT. Meda Cipta Hutama merupakan penyedia jasa IT dan general contractor. Keinginan perusahaan adalah memenuhi kebutuhan pelanggan, di mana diperlukan sebuah sistem informasi yang interaktif. Untuk memenuhi keinginan pelanggan tersebut, dibutuhkan sistem informasi Interactive Customer Relationship Management (i-CRM). I-CRM merupakan suatu usaha untuk menciptakan interaksi antara pelanggan dan perusahaan dengan waktu respon yang tinggi sehingga tidak terjadi kesalahan dalam proses persiapan sampai kepada penyajiannya. Metode pengumpulan data menggunakan metode observasi, wawancara, kuesioner dan studi literatur. Sedangkan metode pengembangan sistem informasinya menggunakan model RAD, yang meliputi UML, dengan diagram use case, sequence class, statechart dan activity. Tujuan pada penelitian ini adalah membangun sistem informasi interactive customer relationship management (i-CRM). Adapun hasil yang diperoleh dari penelitian ini berupa sebuah website i-CRM di mana pihak perusahaan dapat berinteraksi langsung dengan pelanggan dan pelanggan juga dapat dengan mudah melakukan purchase order. Selain itu, i-CRM ini dapat meningkatkan pelayanan yang diberikan yang berdampak pada meningkatnya kepuasan dan loyalitas pelanggan. Sistem ini juga dapat mempermudah perusahaan berinteraksi langsung dengan pelanggan menggunakan fasilitas suggestion dan complain, chatting dan newsletter.
\end{abstract}

Keywords-i-CRM; interactive customer relationship management, analisis rantai nilai, RAD, UML

Received: 5 Februari 2018; Revised: 1 Maret 2018; Accepted: 1 April 2018.

R. H. Handayani, Prodi Sistem Informasi Fakultas Sains dan Teknologi Universitas Islam Negeri Syarif Hidayatullah Jakarta (diajengrahmawati@gmail.com)

Q. Aini, Prodi Sistem Informasi Fakultas Sains dan Teknologi Universitas Islam Negeri Syarif Hidayatullah Jakarta (nia.kumaladewi@uinjkt.ac.id)

E. Nurmiati, Prodi Sistem Informasi Fakultas Sains dan Teknologi Universitas Islam Negeri Syarif Hidayatullah Jakarta (yuni.sugiarti@uinjkt.ac.id)

http://journal.uinjkt.ac.id/index.php/aism

\section{PENDAHULUAN}

Customer Relationship Management (CRM) berkonsentrasi pada apa yang dinilai oleh pelanggan (what customer value). Perusahaan perlu melakukan peningkatan value terhadap produk atau jasa yang dihasilkan, salah satunya dengan memberikan services yang membuat pelanggan loyal sehingga dapat tercapai hubungan dengan baik dengan pelanggan. Tipe CRM dapat diuraikan dalam tiga level: [1]

1. Level fungsional: CRM dapat dipraktikkan secara fungsional yang sangat terbatas (misal: otomasi tenaga penjualan dalam fungsi penjualan, pengelolaan promosi oleh fungsi pemasaran). CRM semacam itu sering digabungkan dengan orientasi teknologi. Bagi beberapa vendor atau pembeli, CRM fungsional hampir identik dengan teknologi.

2. Level customer berhadapan dengan front end (customerfacing front-end): tipe CRM yang berkembang dari kebutuhan praktisi dalam menggambarkan kemampuan bisnis baru atau susunan kemampuan baru yang berfokus pada total pengalaman pelanggan. Tujuannya adalah untuk membangun satu tampilan di semua saluran kontak dan mendistribusikannya ke semua fungsi yang berhubungan langsung dengan pelanggan.

3. Level strategis: CRM adalah sebuah proses yang berpusat pada customer dalam pasar dan membangun nilai shareholder. Pengetahuan tentang customer dan preferensinya memiliki dampak untuk keseluruhan organisasi, seperti R\&D atau supply chain management (SCM).

PT. Meda Cipta Hutama bergerak di bidang penjualan jasa infrastruktur jaringan yang mengutamakan kualitas kerja tinggi dan material terbaik untuk jasa manajemen proyek infrastruktur jaringan. Perusahaan ini memiliki tenaga kerja dan pimpinan yang berpengalaman dan menguasai jasa infrastruktur jaringan. Pelanggan perusahaan ini telah mengetahui kualitas kerja secara personal. Namun, kesulitan bagi perusahaan adalah tidak semua perusahaan lain mengetahui kualitas tenaga kerja perusahaan. Selain itu, PT. Meda Cipta Hutama dalam memberikan informasi kepada pelanggan tentang pengalaman dan kualitas services yang baik dengan memberikan company profile secara hardcopy. 
Company profile tersebut sulit disebarkan sehingga sedikit pelanggan yang tertarik dan melakukan hubungan kerjasama. Selain masalah informasi minim dari company profile, hal yang sering dikeluhkan dan dipertanyakan pelanggan adalah material yang digunakan, services yang disediakan dan informasi terbaru tentang PT. Meda Cipta Hutama.

Penelitian sebelumnya mengenai CRM di bidang jasa, [2] melakukan implementasi penyedia peralatan dna perlengkapan kegiatan outdoor. Sebuah penelitian kualitatif dengan pendekatan action research dengan mengusulkan CRM dengan Zurmo CRM berbasis open source. Hasil penelitian ini adalah pengelolaan manajemen antara perusahaan dan pelanggan menjadi lebih mudah, efektif dan efisien karena menggunakan sistem informasi yang terintegrasi. [3] menawarkan CRM berbasis web yang bertujuan mendapatkan pelanggan dengan mempromosikan informasi produk dan order printing secara online sehingga memudahkan pelanggan untuk bertransaksi. Penelitian lain mengemukakan tentang dampak pengetahuan customer dan kualitas layanan CRM. Hasilnya menunjukkan bahwa pengetahuan pelanggan berpengaruh positif terhadap kualitas layanan dan CRM adalah variabel intervensi parsial antara pengetahuan dan kualitas layanan pelanggan. Rekomendasi penelitian ini menyatakan bahwa perusahaan harus secara efektif mendapatkan pengetahuan pelanggan tentang persepsi mereka tentang kualitas produk dan layanan pelanggan, efektivitas tenaga penjualan dan komunikasi terkait, sehingga mereka dapat mengelola dinamika pelanggan dan tren pasar dengan benar untuk meningkatkan hubungan pelanggan, meningkatkan kualitas layanan secara keseluruhan, dan memajukan daya saing perusahaan [4]. Perkembangan penggunaan media sosial ini yang sangat pesat menyebabkan CRM harus dapat menyesuaikan diri dengan media sosial. Konvergensi media sosial dan CRM menciptakan tantangan dan peluang, yang perlu dieksplorasi. Tantangan yang dimaksud mencakup kurangnya kontrol terhadap penyebaran pesan, kumpulan data yang besar dan tidak terstruktur, privasi, keamanan data, kekurangan tenaga kerja yang berkualitas, pengukuran return of investment (ROI) dari inisiatif pemasaran media sosial, strategi untuk mengelola karyawan, mengintegrasikan pelanggan, dan konten pemasaran [5].

Persaingan yang cukup tinggi dalam bisnis khususnya di bidang jasa infrastruktur jaringan dan kesadaran akan pentingnya pelanggan bagi kelangsungan hidup perusahaan, memotivasi peneliti untuk menyediakan dan membangun sebuah sistem yang dapat mendukung perusahaan dalam menjelaskan kualitas services untuk mempertahankan dan memperluas hubungan dengan pelanggan. Sistem informasi yang diusulkan adalah interactive customer relationship management (i-CRM) berbasis web.

\section{Metode Penelitian}

Adapun langkah pengembangan i-CRM PT. Meda Cipta Hutama terbagi dalam tiga tahap, yaitu tahap persiapan, pelaksaaan dan hasil seperti ditunjukkan pada Gambar 1. Pada tahap persiapan merupakan tahap di mana peneliti mengumpulkan data melalui cara observasi, wawancara, kuesioner, dan studi literatur Sedangkan tahap pelaksanaan adalah tahap membangun i-CRM mengacu pada rapid application development (RAD) [6]. Pada fase perencanaan persyaratan, mencakup identifikasi masalah, tujuan pengembangan sistem, ruang lingkup sistem, analisis sistem berjalan, analisis kebutuhan sistem, analisis CRM, dan sistem yang diusulkan. Analisis CRM digunakan untuk identifikasi pengembangan penerapan strategi CRM dengan melakukan analisis fase acquire (mendapatkan pelanggan baru), fase enhance (meningkatkan hubungan dengan pelanggan yang telah ada) dan fase retain (mempertahankan pelanggan). Sedangkan pada fase desain workshop mencakup desain sistem, database, dan prototype. Pada fase implementasi, pengembangan meliputi pemrograman (coding) dan pengujian blackbox.

Penelitian i-CRM di PT. Meda Cipta Hutama bertujuan meningkatkan kepuasan dan loyalitas pelanggan. Pengembangan dilakukan dengan menggunakan metode berorientasi objek UML [7][8] serta berbasis web PHP, MySQL [9] [10].

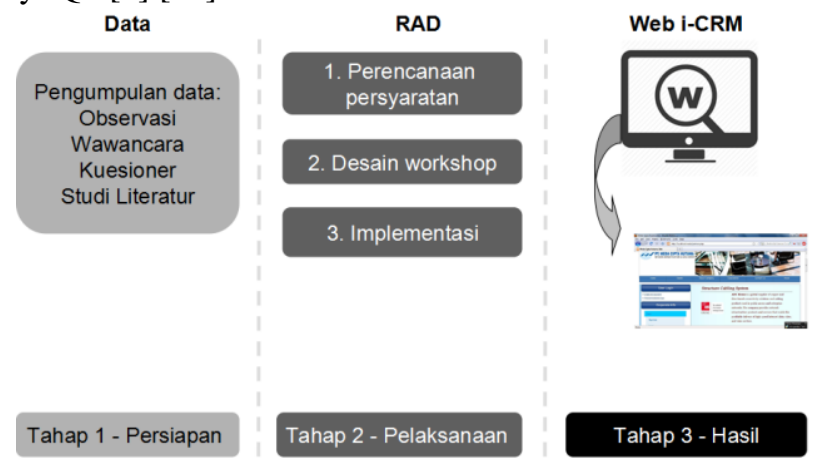

Gambar 1. Tahapan Pengembangan i-CRM

\section{HASIL DAN PEMBAHASAN}

Mengacu pada tahapan pengembangan i-CRM, sesuai dengan tahapan pada RAD diperoleh hasil sebagai berikut:

\section{A. Perencanaan Persyaratan}

Pada identifikasi masalah, terdapat beberapa hal menjadi kendala dalam sistem yang sedang berjalan dalam memenuhi kebutuhan informasi untuk pelanggan guna menjalin hubungan yang baik dengan pelanggan, yaitu sistem manual yang ada belum dapat menyajikan informasi yang dapat membantu pelanggan mendapatkan informasi yang relevan. Pengembangan i-CRM ini bertujuan untuk membantu pelanggan PT. Meda Cipta Hutama dalam melihat informasi yang dibutuhkan seperti company profile, jadwal karyawan, berita, melakukan upload file purchase order, memberikan kritik dan saran, chatting dengan salah satu divisi yang diinginkan, melihat grafik progress project yang sedang berjalan serta mengirimkan informasi menarik keseluruh pelanggan yang membutuhkan melalui e-mail. Sedangkan lingkup sistem berdasarkan hasil identifikasi masalah, yaitu membangun Sistem Informasi Interactive Customer Relationship Management dalam kegiatan berbisnis di internet yang lebih mengutamakan interaksi antara pelanggan dengan perusahaan dalam upaya mengembangkan bisnis dan 
TABEL I

ANALISIS KEBUTUHAN SISTEM

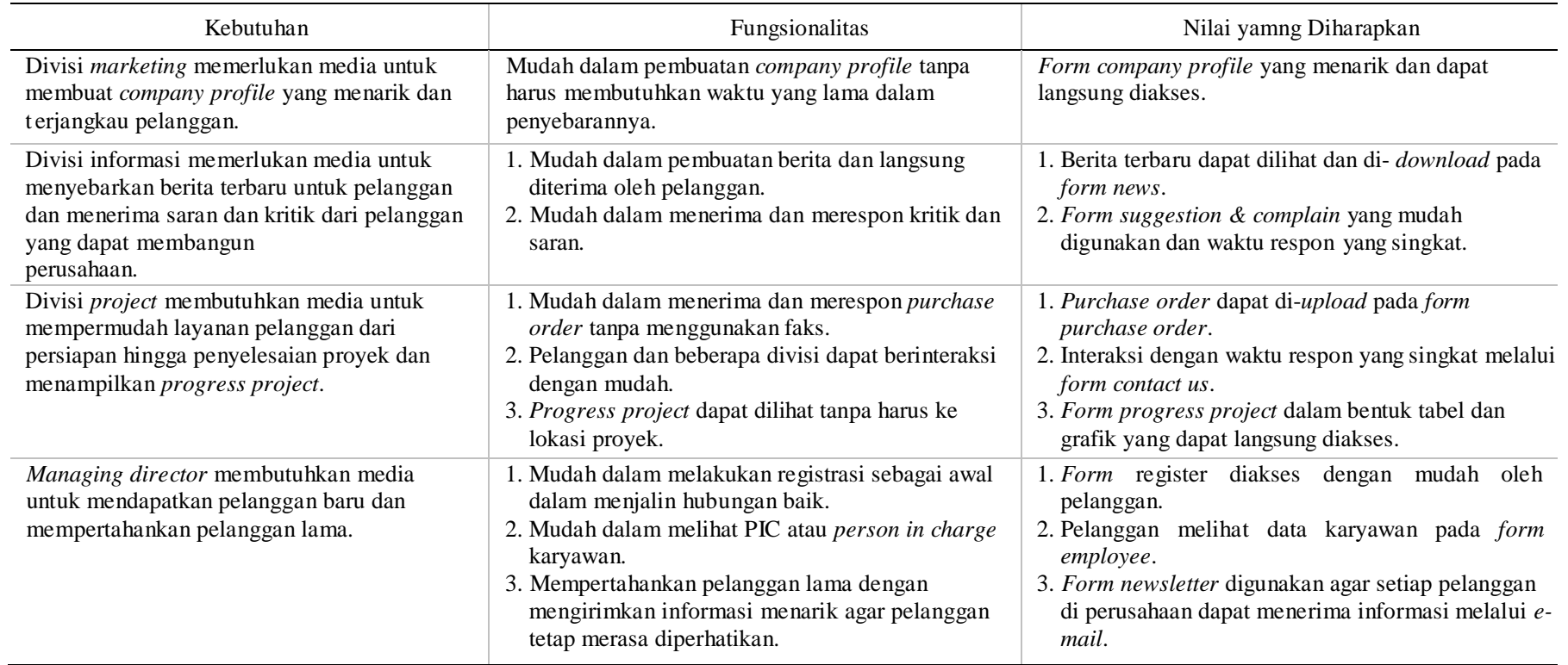

mempertahankan pelanggan melalui layanan Suggestion \& Complain, Chatting dan Newsletter.

PT. Meda Cipta Hutama merupakan perusahaan yang bergerak di bidang jasa infrastruktur jaringan yang memberikan layanan informasi seperti produk dan service, berbagai pengalaman proyek yang telah dikerjakan, mitra aliansi dan informasi terbaru dari perusahaan masih menggunakan sistem manual. Manual di sini dalam mendapatkan informasi, pelanggan tersebut sulit mendapatkan company profile karena penyebarannya hanya sampai ke beberapa pelanggan yang dikenal. Selain itu company profile yang disebarkan ke perusahaan lain atau pelanggan masih kurang menarik minat pelanggan untuk mengetahui isi dari company profile tersebut. Apabila pelanggan tertarik dengan company profile tersebut dan hendak memberikan proyek, maka pelanggan akan menghubungi PT. Meda Cipta Hutama. Kemudian PT. Meda Cipta Hutama melakukan survei ke proyek yang akan ditangani dan sebagai hasilnya adalah memberikan quotation/estimasi penawaran proyek ke pelanggan. Setelah mendapatkan quotation biasanya pelanggan menginginkan revisi harga projek atau diskon. Quotation berisi revisi harga proyek yang dipertimbangkan PT. Meda Cipta Hutama, serta periode pembayaran yang disesuaikan dengan kontrak perjanjian kerjasama. Quotation dicatat beserta informasi berupa nama pelanggan, material yang dibutuhkan, kesepakatan pembayaran pada periode tertentu, pajak yang harus ditanggung pelanggan dan perincian harga untuk jasa pekerja proyek. Setelah negosiasi harga telah terjadi kesepakatan maka pelanggan akan memberikan Purchase Order (PO) atau Surat Perintah Kerja (SPK). Pelanggan dapat melakukan purchase order melalui dua cara yaitu bertemu langsung dengan project manajer atau dapat juga mengirimkan PO melalui faks dan e-mail. Setelah proyek berjalan, pelanggan mendatangi lokasi proyek untuk melihat progress project yang dikerjakan engineer PT. Meda Cipta Hutama. Setelah proyek selesai dikerjakan maka divisi project memberikan invoice kepada pelanggan.

Tampilan i-CRM yang disajikan hendaknya user friendly dan memudahkan pelanggan mengakses sistem tersebut serta mampu memberi informasi yang diperlukan pelanggan, dengan cara membangun komunikasi dengan pelanggan. Tabel 1 menjelaskan kebutuhan sistem yang diharapkan mampu memberi informasi yang dibutuhkan pelanggan. Dari hasil pengamatan yang dilakukan terdapat masalah yang kemudian dilakukan proses analisis dengan menggunakan analisis Customer Relationship Management (CRM). Sistem yang dirancang ini memenuhi tahapan strategi dalam CRM, yaitu: [11]

1) Fase acquire, merupakan fase dimana melalui website ini perusahaan berusaha mendapatkan pelanggan baru. Tahap acquire bagi PT. Meda Cipta Hutama adalah ketika calon pelanggan (non member) tertarik akan produk atau jasa yang ditawarkan, tahap ini terdiri dari modul company profile dan register.

2) Fase enhance, merupakan fase dimana melalui website ini perusahaan berusaha meningkatkan hubungan dengan pelanggan yang telah ada. Tahap ini terdiri dari modul purchase order, progress project, employee dan news.

3) Fase retain, merupakan tahap dimana melalui website ini perusahaan berusaha mendapatkan loyalitas pelanggan dengan mendengarkan pelanggan dan berusaha memenuhi keinginan pelanggan. Tahap ini terdiri atas modul chatting, newsletter \& modul suggesstion \& complain.

Berdasarkan identifikasi masalah dan bagan sistem yang sedang berjalan tersebut, maka penulis mengusulkan untuk 
membangun sebuah aplikasi yang memudahkan pelanggan dalam mendapatkan informasi tentang PT. Meda Cipta Hutama. Aplikasi yang dibangun ini memiliki interface yang menarik dan user friendly serta tidak membuat bingung pelanggan dalam memperoleh informasi. Dari hasil

wawancara dengan Direksi PT. Meda Cipta Hutama, mereka juga menginginkan sebuah website untuk perusahaannya yang berfungsi sebagai company profile. Oleh karena itu peneliti menggabungkan sebuah website dengan i-CRM yang dikembangkan, membuat suatu sistem yang efektif dan efisien dan telah diketahui bersama bahwa hasil informasinya, sistem yang berbasis web itu, dapat diakses kapan saja dan di mana saja (Gambar 3).

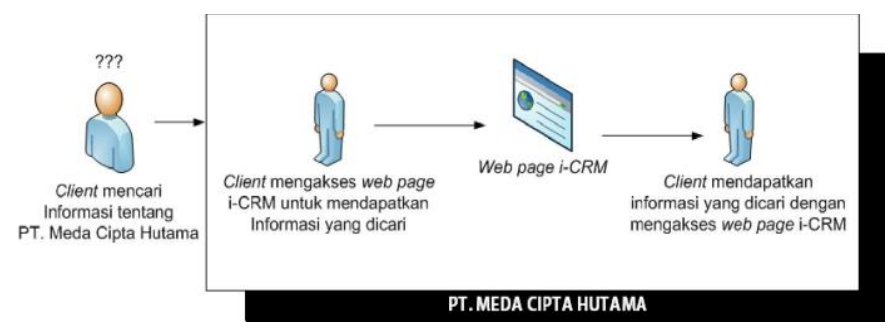

Gambar 2. Rich Picture Sistem Usulan

\section{B. Desain Workshop}

Pada tahap workshop design, dibuat desain yang merupakan solusi dari hasil analisis pada tahap requirement planning. Pada fase konsep i-CRM (Interactive Customer Relationship Management), terdapat tiga tahap yang terlihat dalam sistem, yaitu tahap pengalaman pre penjualan, tahap pengalaman saat penjualan dan tahap pengalaman pasca penjualan. Dalam penerapan pada sebuah aplikasi pemberian informasi kepada pelanggan maka pengalaman pre penjualan adalah di saat pelanggan ingin mendapat informasi lebih lengkap tentang PT. Meda Cipta Hutama dan belum menjadi member. Sedangkan masa saat penjualan yaitu masa di saat pelanggan telah terdaftar sebagai member dan melakukan pencarian informasi tentang PT. Meda Cipta Hutama. Dan pasca penjualan itu adalah masa di saat pelanggan telah mendapatkan respon atau feedback dari aplikasi ini berupa e-mail, melakukan interaksi dengan sistem lewat chatting dan telah melakukan pencarian informasi. Aktivitas yang dilakukan pelanggan dalam tiap tahapan i-CRM berdasarkan hasil wawancara dan observasi. Konsep i-CRM tersebut menghasilkan perancangan yang digambarkan pada Gambar 3. Alur proses sistem i-CRM digambarkan dengan menggunakan diagram UML yang terdiri atas use case diagram, sequence diagram, class diagram, statechart diagram dan activity diagram. Pada use case diagram meliputi: (1) identifikasi aktor yang terdiri atas non-member, member, admin, Divisi Project, Divisi Marketing, Divisi Informasi, dan Divisi Personalia (Tabel 2); (2) Identifikasi use case di mana terdapat 11 use case; (3) use case diagram; dan (4) narasi use case. Adapun pada fase database meliputi spesifikasi database dan prototype desain.

\section{Penerapan}

Alur proses sistem i-CRM digambarkan dengan menggunakan diagram UML [8] yang terdiri atas use case diagram, sequence diagram, class diagram, statechart diagram dan activity diagram. Pada use Pada tahap ini di mana prototype telah disempurnakan dan disesuaikan dengan keinginan user. Dan tahap ini disebut juga tahap implementasi. Jadi, sistem yang telah dianalisis dan didesain telah di-review oleh user kemudian dilakukan revisi hingga sesuai dengan keinginan user sehingga sistem ini akhimya sempurna dan tiba saatnya sekarang sistem ini untuk diimplementasikan (diterapkan). Tahap implementasi sistem merupakan tahap meletakkan sistem supaya siap untuk dioperasikan.

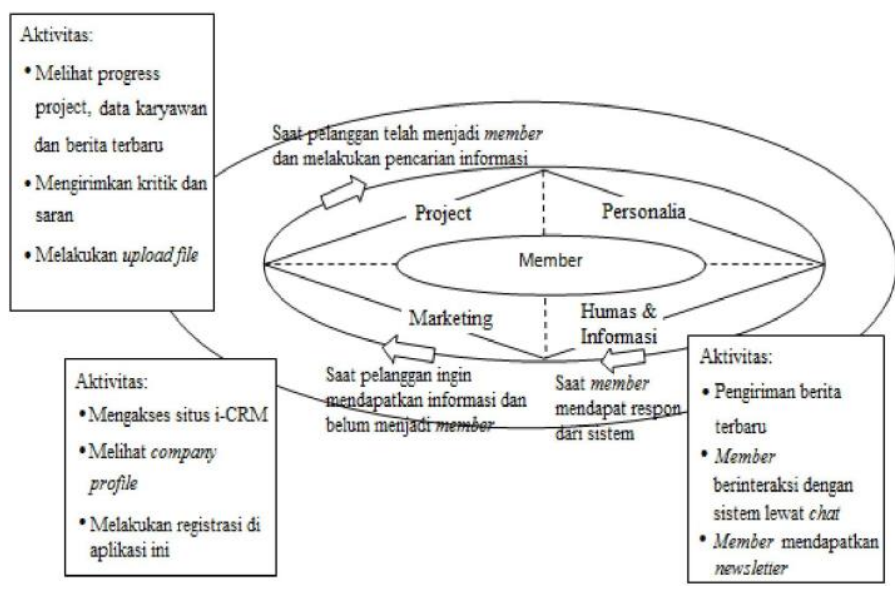

Gambar 3. Konsep i-CRM PT. Meda Cipta Hutama

TABEL II

IDENTIFIKASI AKTOR

\begin{tabular}{|c|c|c|}
\hline No. & Actor & Deskripsi \\
\hline 1. & Non-member & $\begin{array}{l}\text { Orang yang hanya memiliki hak akses } \\
\text { untuk melihat company profile/promosi dan } \\
\text { melakukan registrasi agar dapat melakukan } \\
\text { interaksi dengan sistem. }\end{array}$ \\
\hline 2. & Member & $\begin{array}{l}\text { Orang yang telah terdaftar dalam sistem } \\
\text { yang dapat melihat company profile, news, } \\
\text { meng-upload purchase order, melihat } \\
\text { progress project dan Person In Charge } \\
\text { (PIC) karyawan PT. Meda Cipta Hutama. } \\
\text { Selain itu member tersebut dapat } \\
\text { berinteraksi dengan berbagai divisi lewat } \\
\text { chatting, memberikan saran dan keluhan } \\
\text { melalui fasilitas suggestion \& complain dan } \\
\text { mendapatkan info menarik tiap bulan dari } e \text { - } \\
\text { mail. }\end{array}$ \\
\hline 3. & Admin & $\begin{array}{l}\text { Admin merupakan super class dari child } \\
\text { class divisi project, divisi marketing, divisi } \\
\text { personalia dan divisi informasi. Admin dapat } \\
\text { mengontrol seluruh kegiatan dalam sistem. }\end{array}$ \\
\hline 4. & Divisi Project & $\begin{array}{l}\text { Orang yang dapat menanggapi puchase } \\
\text { order dari member dengan mengirimkan } e \text { - } \\
\text { mail sebagai persetujuan pengerjaan proyek } \\
\text { kemudian menampilkan progress project } \\
\text { yang sedang dikerjakan kepada member. }\end{array}$ \\
\hline 5. & Divisi Marketing & $\begin{array}{l}\text { Orang yang dapat melihat data registrasi } \\
\text { member dan me-record data company } \\
\text { profile. }\end{array}$ \\
\hline 6. & Divisi Informasi & $\begin{array}{l}\text { Orang yang dapat merespon suggestion \& } \\
\text { complain. Suggestion \& complain direspon } \\
\text { melalui e-mail, selain itu menanggapi } \\
\text { dengan meng-update data news sebagai } \\
\text { promosi untuk member. }\end{array}$ \\
\hline 7. & Divisi Personalia & $\begin{array}{l}\text { Orang yang dapat me-record data karyawan } \\
\text { atau Person In Charge (PIC) }\end{array}$ \\
\hline
\end{tabular}


Implementasi dilakukan dengan melakukan coding (pemrograman) dan meng-upload semua file i-CRM ke penyedia web-hosting, dalam hal ini peneliti menggunakan domain MEDATAMA.COM dan sistem sudah dapat digunakan oleh user. Menurut hasil wawancara dengan pimpinan perusahaan, perlunya penambahan fitur kritik dan saran serta modul Divisi Personalia dengan menu data karyawan. Pengujian sistem dilakukan dengan menggunakan metode blackbox testing. Cara pengujian dilakukan dengan menjalankan i-CRM dan melakukan input data serta melihat output-nya apakah sesuai dengan proses bisnis yang diharapkan. Hasil pengujiannya ternyata sesuai dengan proses bisnis yang diharapkan.

Implementasi dilakukan dengan melakukan coding (pemrograman) dan meng-upload semua file i-CRM ke penyedia web-hosting, dalam hal ini peneliti menggunakan domain MEDATAMA.COM dan sistem sudah dapat digunakan oleh user. Menurut hasil wawancara dengan pimpinan perusahaan, perlunya penambahan fitur kritik dan saran serta modul Divisi Personalia dengan menu data karyawan. Pengujian sistem dilakukan dengan menggunakan metode blackbox testing. Cara pengujian dilakukan dengan menjalankan i-CRM dan melakukan input data serta melihat output-nya apakah sesuai dengan proses bisnis yang diharapkan. Hasil pengujiannya ternyata sesuai dengan proses bisnis yang diharapkan.

\section{KESIMPULAN}

Penelitian ini merancang dan membangun Interactive Customer Relationship Management berbasis web PT. Meda Cipta Hutama dan berdasarkan hasil wawancara, i-CRM sesuai dengan kebutuhan owner dalam meningkatkan hubungan antara perusahaan dan pelanggan demi terjalinnya sebuah loyalitas mitra. Dengan diterapkannya Interactive Customer Relationship Management, PT. Meda Cipta Hutama dapat berinteraksi langsung dengan pelanggan menggunakan fasilitas suggestion \& complain, chatting dan newsletter. Fasilitas suggestion \& complain digunakan agar member dapat memberikan kritik dan saran guna membangun perusahaan, fasilitas chatting adalah fasilitas chatting yang disediakan agar member dapat dengan mudah menghubungi perusahaan dan fasilitas newsletter digunakan agar member mendapatkan informasi menarik mengenai event perusahaan, ucapan selamat Hari Raya atau seputar project yang telah dilakukan perusahaan. Fasilitas ini merupakan salah satu upaya untuk mempertahankan pelanggan. Mengacu pada hasil kuesioner setelah web CRM diperlihatkan pada customer PT. Meda Cipta Hutama, dapat disimpulkan bahwa 73,33\% customer menyatakan informasi yang diberikan aplikasi i-CRM sudah memadai dan $40 \%$ menyatakan bahwa cara penggunaan iCRM ini sangat mudah. Informasi tersebut tentang data karyawan, data berita, data company profile dan data progress project telah tersaji secara relevan. Seluruh customer (100\%) menyatakan bahwa dengan adanya i-CRM ini dapat meningkatkan kualitas dan kuantitas layanan. Adapun penelitian mendatang tentang implementasi CRM perlu dipertimbangkan adalah fasilitas security sebagai peran penting pada cloud CRM serta tantangan yang dihadapi pada social CRM menjadi kajian menarik untuk diteliti lebih lanjut.

\section{DAFTAR PUSTAKA}

[1] Kumar V., Reinartz, W. Customer Relationship Management: Concept, Strategy, and Tools. $2^{\text {nd }}$ Edition. Springer. 2012.

[2] Randy, M.I.D, Astuti, E.S, Riyadi. Implementasi Sistem Informasi CRM (Customer Relationship Management) (Studi pada UD. Iwek-P Adventure Kota Malang). Jurnal Administrasi Bisnis. 2014; 15(2): 2-10.

[3] Al Amin, I.H, Kristanto. Aplikasi Customer Relationship Management (CRM) di CV. Matahari Digital Printing Semarang. Jurnal Ilmiah Dinamika Teknik. 2014; 8(2): 49-65.

[4] Tseng, S.-M., Wu, P.-H. The impact of customer knowledge and customer relationship management on service quality. International Journal of Quality and Service Sciences. 2014; 6(1): 77-96.

[5] Malthouse, E.C., Haenlein, M., Skiera, B., Wedge, E., Zhang, M. Managing Customer Relationships in the Social Media Era: Introducing the Social CRM House. Journal of Interactive Marketing. 2013; 27: 270-280.

[6] Naz, R., Khan, M.N.A. Rapid Applications Development Techniques: A Critical Review. International Journal of Software Engineering and Its Applications. 2015; 9(11): . 163-176.

[7] Wirawan, I.M.A. Pemrograman Berorientasi Objek. Edisi 2. Yogyakarta: Graha Ilmu. 2014.

[8] Lee, S. Unified Modeling Language (UML) for Database Systems and Computer Applications. International Journal of Database Theory and Application. 2012; 5(1): pp. 157-164.

[9] Raharjo, B. Modul Pemrograman WEB (HTML, PHP, \& MySQL). Edisi 3. Bandung: Modula. 2016.

[10] Sianipar, R.H. Membangun Web dengan PHP \& Mysql untuk Pemula dan Programer. Bandung: Informatika. 2015.

[11] Buttle, F., Maklan, S. Customer Relationship Management: Concepts and Technologies. Third Edition. Oxon: Taylor \& Francis Group. 2015. 
